\title{
Electronic Communication of Non-Profit Organizations in a Global Society
}

\author{
Dagmar Hraskova ${ }^{1, *}, Z^{*}$ zana Rosnerova $^{1}$ \\ ${ }^{1}$ University of Zilina, Faculty of Operation and Economics of Transport and Communications, \\ Department of Economics, Univerzitna 1, 01026 Zilina, Slovakia
}

\begin{abstract}
.
Research background: Communication of non-profit organizations is one of the key activities in the conditions of this type of organizations, because through flexible communication, non-profit organizations can function effectively in today's global society, based on modern information and communication technologies. In 2020, there was a change in communication with non-profit organizations in the environment of the Slovak Republic, through the establishment of electronic mailboxes.

Purpose of the article: The aim of the article is to analyse a new way of communication of non-profit organizations, which results from the new legislation, which was adopted under Slovakia in 2020 and came into force on June 1, 2020, when the state gradually established and activated for electronic mailbox delivery for individual non-profit entity.

Methods: Analytical methods were used in the article in order to evaluate the suitability of electronic mailboxes and their benefits in the environment of non-profit organizations. We work with the hypothesis that this method of communication will bring significant changes for the non-profit sector in the form of benefits, which will eliminate the obstacles that were present in the postal communication and will speed up the mutual exchange of information.

Findings \& Value added: The year 2020 thus brought a change in electronic mailboxes and Slovakia introduced the establishment of these mailboxes for non-profit organizations as well. Based on the obligation of non-profit organizations and its deeper analysis, we identify the advantages and disadvantages that result from this method of communication and evaluate their contribution for the practice of nonprofit organizations.
\end{abstract}

Keywords: communication of non-profit organizations, electronic mailboxes, non-profit sector

JEL Classification: $M 38 ; L 31 ; F 60$

\footnotetext{
*Corresponding author: dagmar.hraskova@,fpedas.uniza.sk
} 


\section{Introduction}

The world around us is full of information, and information is a kind of knowledge for everyone. We can perceive information through our senses. In the field of e-government, information can be understood from several perspectives. E-government is basically the electronic functioning of government and the interconnection between the entities that fall within its coverage. The national economy also includes non-profit entities, which are a very important element of national economies [1]. These entities have a specific focus and their goal is not to report profits but to provide public services [2]. Communication between non-profit entities and the government is currently possible in the Slovak Republic through electronic communication. Communication is important not only in terms of official matters, but also in the case of the existence and successful operation of a non-profit organization in the market. In order for a non-profit organization to be able to engage the environment with its program and mission, it uses communication for this purpose [3]. In many cases, people's emotions play an important role in decision-making in the target groups to which communication is aimed $[4,5]$. Based on the emotional aspects of potential donors and volunteers, interest may be aroused, which may eventually become a real part of a non-profit organization.

Today, information has already lost its direct connection with the human world, mainly due to cybernetics, and its application began to be applied as part of all processes in which a certain transformation takes place [6]. Modern communication technologies are the best way to present information in today's global environment [7]. Information represents the content of the process of human communication, transmission and reception of notifications and their transmission can be realized through personal contact, sound, signal, or other means of mass communication [8]. Information, together with material, energy and financial resources, is currently one of the main drivers of progress in all areas of human activity [9]. The term communication comes from the Latin dictionary and its meaning can be understood as a process of transmission, mediation and subsequent collection of information. Communication is currently understood as the basis of interpersonal contact and its pillar is the mutual exchange of information, messages and meaning between individuals or groups [10]. In the process of globalization, which is now understood as a common element for the functioning of the world and the movement of the world, the electronic form of communication via electronic mail, as well as communication via social networks, discussion forums and also electronic mailboxes, gain the greatest importance [11]. In the context of electronic communication, it is also easier for the staff of the authority. Through electronic communication, a certain degree of automation of the distribution of messages takes place, and consequently it is also possible to keep messages easier to record [12-14]. Electronic communication is one of the most widely used forms of communication between organizations in today's modern world through application software systems $[15,16]$. The information system consists of several activities, which include the collection of information, its processing, storage, retrieval and dissemination. There are other elements connected to the information system, among which we could include information documents, information technology workers and information processes $[17,18]$. The following figure shows the components of the information system. 


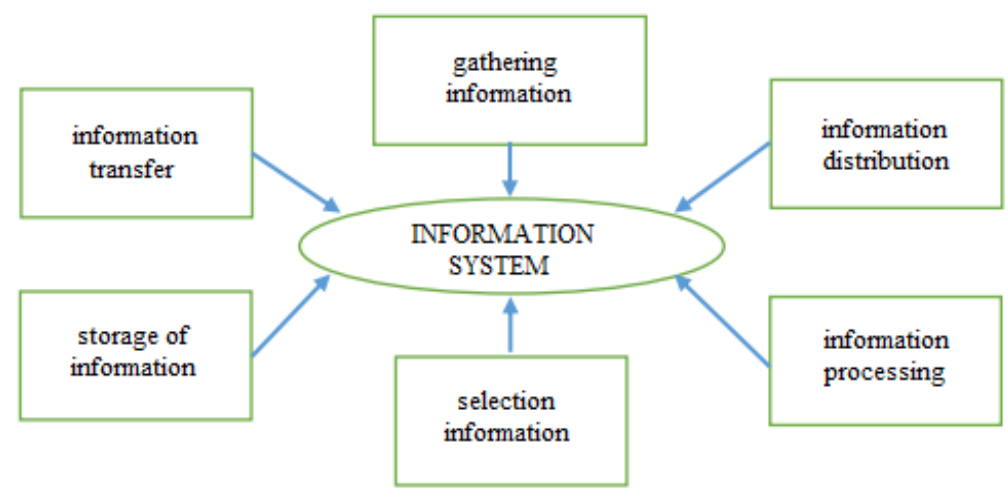

Fig. 1. Elements of the information system

The field of e-government is basically electronic government, which is already established in the Slovak Republic. It is an electronic interaction involving public administration and citizens and using information as well as communication technologies, i.e. communication between the citizen and the state through electronic communication [19]. Its aim is to ensure easier, cheaper and more reliable provision of public administration services.

According to the type of communication and its participants, e-government is divided into the following levels:

- $\mathrm{G} 2 \mathrm{C}$ (Government to Citizens) - between public administration and citizens

- G2B (Government to Businesses) - between public administration and business

- sphere

- G2E (Government to Employees) - within public administration institutions

- G2G (Government to Governments) - between public administration institutions

- G2A (Government to Administration) - between public administration and

- administration

- $\mathrm{C} 2 \mathrm{G}$ (Citizens to Governments) - communication of citizens towards the authorities

- public administration [20].

Within each of these levels, there are four basic types of activities, namely:

- providing general information to citizens via the Internet

- ensuring communication between the Office and citizens, businesses or offices with each other,

- execution of money transfers,

- governance, which extends the principles to the general public, making it possible to participate in governance through information and communication technologies [21]. The aim of e-government is to enable the handling of official matters from one place via an Internet connection to remove barriers associated with a large number of requests for information, data and documents of citizens in areas where there is interaction between public administration and citizens, or businesses and would lead to speed up the processes themselves. The author of Fabryova sees an advantage mainly in the elimination of time consuming in dealing with official matters, the minimization of errors and the elimination of multiple performances of the same tasks [22].

The article focuses on the issue of introducing e-government to the non-profit sector in the Slovak Republic. The aim of the article is to specify the benefits and disadvantages of the newly introduced communication tool for organizations operating in the non-profit sector, as well as to identify the obligations that will arise from the use of this communication tool for non-profit organizations. Analytical and descriptive methods were 
used in solving the problem and evaluating the effectiveness of electronic mailboxes for non-profit entities.

\section{Methods}

Electronic mailboxes represent an effective way of communication of selected subjects with other parties. The year 2020 represents a certain milestone for the area of the Slovak nonprofit sector, because the obligation to have an activated electronic mailbox also affected entities operating in the non-profit sector. In 2014, electronic mailboxes within the public authorities were activated in the territory of the Slovak Republic; in 2017, there was an obligation for legal entities registered in the Commercial Register. On 1 June 2020, this obligation also arose for legal entities operating outside the Commercial Register. This group of entities includes more than 78,880 entities from the third sector, namely foundations, non-profit organizations, church organizations, interest groups and political parties, for which the obligation to have an activated electronic mailbox for the delivery of official decisions has arisen.

The conditions for electronic communication with public authorities are regulated by the Act on e-Government, which has been amended several times since its promulgation and contains many transitional provisions with several exceptions and different arrangements for electronic communication of various types of entities. To the civic associations and other non-business legal entities, the authorities began to deliver documents only to their electronic mailbox, starting on 1 June 2020 pursuant to $\S 60 \mathrm{~b}$ para. 3 of Act no. 305/2013 Coll. on the electronic form of the exercise of powers by public authorities and on the amendment of certain laws (the e-Government Act) as amended. The actual activation of electronic mailboxes is automatic and will take place gradually, in several phases, as it is an extremely large group of legal entities.

Electronic mailboxes are used for electronic communication of citizens and entrepreneurs with public authorities and their goal is to achieve more efficient and faster communication of these entities with the public administration. Electronic mailboxes are set up through the Office of the Deputy Prime Minister of the Slovak Republic for Investments and Informatization for natural persons, natural persons - entrepreneurs, legal entities, public authorities and subjects of international law. The mailbox of natural persons is set up automatically for citizens of the Slovak Republic who have reached the age of 18 . In order for the e-mail box to be used for electronic delivery, it must first be activated so that message delivery can take place. Mailboxes of public authorities are activated for delivery at the same time as their establishment. Citizens and individuals - entrepreneurs can apply for activation at any time. All mailboxes of legal entities that are registered in the Commercial Register and have their registered office in the territory of the Slovak Republic are obligatorily activated for delivery from 1 July 2017 and from 1 June 2020 the same process also affected mailboxes of legal entities that are not registered in the Commercial Register.

As far as the activation of the electronic mailbox is concerned, it is a process that enables its use for electronic delivery of messages to the given subject from public authorities. In practice, this means that, by means of an activated electronic mailbox, it is possible to take electronic decisions from public authorities which have the same legal effect as if they had been delivered in paper form.

As we mentioned above, there are four phases associated with the issue of electronic mailboxes. In the first phase, which took place on 1 June 2020, e-mailboxes were activated for delivery to foundations, non-investment funds, non-profit organizations providing services of general interest, civic associations, trade unions and employers' organizations, political parties and movements, legal interest groups and organizations with international 
element. If the said entities did not use the e-mailbox at that time and did not have it activated for delivery, this happened no later than the tenth day from this date, i.e. those organizations whose mailboxes were set up on 1 June 2020 could already be official decisions delivered to the mailbox by 11 June 2020 .

In the case of legal entities that are registered in registers other than those listed, the activation of electronic mailboxes took place in the next four phases on the basis of an individual schedule.

The reason for this shift was the need to continuously clean up, supplement and update the data on these organizations so that they could set up the mailbox and activate it properly. The state was to deliver official decisions in writing to these entities, with the exception of organizations that voluntarily activated the electronic mailbox on 31 May 2020 , even after the deadline of 1 June 2020 until the day of activation of their e-mailboxes.

The second phase of the activation of e-mailboxes began on 1 August 2020 and covered church and religious societies, hunting organizations and legal entities that derive legal personality from the legal personality of churches and religious societies.

The third phase of activation of e-mailboxes takes place from 1.9.2020 for funds, the chamber (with the exception of professional chambers), land communities, the register of European groupings of territorial cooperation and the professional organization - the professional chamber. Subjects such as associations of owners of flats and non-residential premises, public research institutions and public institutions (public and state universities) will have an activated e-mailbox from 1.11.2020.

The fourth phase of e-mailbox activation will be determined for other legal forms (after legal assessment of their status) until 1.1.2021.

If the owner of the electronic mailbox does not have a computer or for some reason does not want to access the electronic mailbox, the law also contains this fact. In such a case, the owner of the electronic mailbox may grant the right of access and the possibility to dispose of the e-mail box to another person authorized by the statutory authority and determine the scope of this right. However, it is important that the statute trusts this person. The owner of the electronic mailbox can send an application for authorization via an authorized electronic document, which he delivers to the administrator of the electronic mailbox module (National Agency for Network and Electronic Services) either through a dedicated electronic mailbox function or through a document in paper form with officially certified signature clipboard.

\section{Results and Discussion}

We consider the introduction of electronic mailboxes for the area of non-profit organizations to be a beneficial tool, not only for the non-profit organizations themselves, but also for the state. There are several advantages that this tool brings to economic practice. First of all, it is a time saving, which is achieved through the fact that the communication takes place through electronic communication channels, i.e. through the Internet. This eliminates the time required, which was difficult before the introduction of electronic communication, mainly due to lengthy processing and waiting at the post office. The submission of documents in electronic form can be submitted throughout the day, without a time limit and without the need to wait in line. The practice of non-profit organizations often shows that non-profit organizations often have a problem with time and not enough. Another advantage is accessibility, where it is now possible to send various official documents from all places thanks to the Internet, the only condition in this case is to have a computer and associated Internet connection and software. Electronic communication is also associated with financial savings, which are significant compared to the usual principle of communication applied until 1 June 2020, compared to when 
documents were sent by letter. Non-profit organizations are entities whose goal is not to make a profit, but to provide public utility services. And that is why non-profit organizations often struggle with financial problems and their available amount of funding is in most cases insufficient. Therefore, in the case of financial aspects, electronic mailboxes are a really large and especially economical variant of possible communication of non-profit entities. The method of communication is a means of developing a non-profit organization, not only towards employees or volunteers, but also towards donors [23].

Another advantage is safety. With electronic mailboxes, their security is comparable to the security of electronic banking and the risk of losing a letter item is eliminated. Also, information is much better in this way of communication, because the user is informed through notification messages.

We can also consider it an advantage that the establishment of an electronic mailbox is free of charge and only certain services are charged, which are above standard and are enshrined in a decree of the Office of the Government of the Slovak Republic. Abovestandard services include expanding the capacity of the mailbox or long-term storage of electronic documents. The non-profit entity has no worries with the establishment of this box, because the establishment is the responsibility of the Office of the Government of the Slovak Republic. In the event that there is a problem with the use of the e-mail box, everything can be solved through the website, where information is also available on how to solve the problems.

With regard to the possible cancellation of the electronic mailbox, this is only possible in exceptional cases, and the applicant, i.e. the non-profit entity, cannot cancel it spontaneously. The Office of the Government of the Slovak Republic shall cancel the electronic mailbox and delete its contents after three years from the day when it learns of the death of the electronic mailbox owner, declaration of the electronic mailbox owner dead or if the electronic mailbox owner - i.e. the non-profit organization itself ceases to exist. However, a non-profit organization can request the deactivation of the electronic mailbox, but it must meet the conditions stipulated by law.

\section{Conclusion}

Information and communication technologies are really important in today's global environment. With the advancing time, which is constantly advancing and is associated with the development of digitization, which has great potential for Slovakia and is not the only reason why our country is increasingly focusing on digitization. Digitization has in the past affected certain categories of entities, including public authorities and legal entities, but as of 1 June 2020, digitization has also covered entities operating in the non-profit sector for which electronic mailboxes have been set up for more efficient communication. In the article, we prepared an analysis of the electronic mailbox system, the aim of which was to specify the benefits for these entities. The hypothesis we worked with was based on the assumption that the establishment of electronic mailboxes for non-profit organizations will bring several benefits not only for the organizations themselves, but also for the state. Based on the solution of the mentioned issue, we came to the conclusion that through this communication tool a space was created for effective communication, which brought not only time savings, availability and information, but also financial and security benefits.

The paper is an output of the science project VEGA 1/0544/19 Formation of the methodological platform to measure and assess the effectiveness and financial status of non-profit organizations in the Slovak Republic.

\section{References}


1. Berenguer, G., Shen, Z.J. (2020). Challenges and Strategies in Managing Nonprofit Operations: An Operations Management Perspective. M\&som-manufacturing \& service operations management, 22(5), 888-905.

2. Rebetak, F., Bartosova, V. (2020). Non-profit organizations in the conditions of Slovakia. SHS Web of Conferences, 74, Art. No. 05020.

3. Shemyatikhina, L., Shipitsyna, K., Usheva, M. (2020). Marketing management of a non-profit organization. Ekonomicko-manazerske spektrum, 14(1), 19-29.

4. Nadanyiova, M. 2017. Neuromarketing - An opportunity or a threat? Communications: scientific letters of the University of Žilina, 19(4), 90-94.

5. Bauerova, R. (2018). Consumers' decision-making in online grocery shopping: The impact of services and delivery conditions. Acta Universitatis Agriculturae et Silviculturae Mendelianae Brunensis, 66(5), 1239-1247.

6. Krizanova, A., Lăzăroiu, G., Gajanova, L., Kliestikova, J., Nadanyiova, M., Moravcikova, D. (2019). The Effectiveness of Marketing Communication and Importance of Its Evaluation in an Online Environment. Sustainability, 11(24), Art. No. 7016.

7. Kolarovszki, P., Kolarovszka, Z., Tengler, J. (2017). Electronic support by the multimedia applications in conjunction with education in the field of postal processes. In L.G. Chova, A.L. Martinez \& I.C. Torres (Eds.). Inted2017: 11th International Technology, Education and Development Conference (pp. 5691-5697). Valencia: Spain.

8. Pitsakis, K., Giachetti, C. (2020). Information-based imitation of university commercialization strategies: The role of technology transfer office autonomy, age, and membership into an association. Strategic Organization, 18(4), 573-616.

9. Crotty, J., Ljubownikow, S. (2019). Restrictive Institutions and Critical Resources: Non-Profit Organisations and Volunteer Resources in the Russian Federation. EuropeAsia Studies, 72(1), 99-116.

10. Boros, J. (2001). Základy socialnej psychologie. Bratislava: IRIS.

11. Klepek, M. (2017). Systematic Analysis of the Current Academic Research on Social Media Marketing. Scientific Annals of Economics and Business, 64(s1), 15-27.

12. Vellino, A., Alberts, I. (2016). Assisting the appraisal of e-mail records with automatic classification. Records Management Journal, 26(3), 293-313.

13. Bracinikova, V., Matusinska, K. (2020). Brand Meaning for Consumers from Dissimilar Generations. Scientific Papers of the University of Pardubice, Series D, 28(1), 29-42.

14. Bauerova, R. (2019). Online grocery shopping acceptance: the impact on the perception of new technologies and loyalty in retailing. Central European Business Review, 8(3), 18-34.

15. Omojokun, E., Adekoya, A., Eyob, E. (2007). A cost-effective approach for migrating enterprise electronic mail systems. In A. Tremante, F. Malpica, A. Oropeza, F. Welsch, J.V. Carrasquero \& H.F. Su (Eds.). Imsci '07: international multi-conference on society, cybernetics and informatics (pp. 320-324). Orlando: Florida.

16. Klepek, M., Starzyczna, H. (2018). Marketing Communication Model for Social Networks. Journal of Business Economics and Management, 19(3), 500-520.

17. Allison-Cassin, S. (2020). Bodies, Brains, and Machines: An Exploration of the Relationship between the Material and Affective States of Librarians and Information Systems. Library Trends, 68(3), 409-430. 
18. Vastikova, M., Matusinska, K., Vanek, J. (2011). Aspekty marketingové komunikace vysoké školy vzhledem k získání nových zákazníků. E+M Ekonomie a management, 3 , 110-116.

19. Bournaris, T. (2020). Evaluation of e-Government Web Portals: The Case of Agricultural e-Government Services in Greece. Agronomy-Basel, 10(7), 932.

20. Mouna, A., Nedra, B., Khaireddine, M. (2020). International comparative evidence of e-government success and economic growth: technology adoption as an anti-corruption tool. Transforming Government- People Process and Policy, Early Access: June 2020.

21. Perez-Morote, R., Pontones-Rosa, C., Nunez-Chicharro, M. (2020). The effects of egovernment evaluation, trust and the digital divide in the levels of e-government use in European countries. Technological Forecasting and Social Change, 154.

22. Fabryova, L. (2007). Informatizacia verejnej spravy. Informatizacia. Retreieved from: http://www.informatizacia.sk/egovernment/519s.

23. Coupet, J., Broussard, P. (2020). Do Donors Respond to Nonprofit Performance? Evidence from Housing. Public performance \& management review. 